\title{
MRX87 family with Aristaless $X$ dup24bp mutation and implication for polyAlanine expansions
}

Carmela Laperuta ${ }^{1}$, Letizia Spizzichino ${ }^{2}$, Pio D'Adamo ${ }^{3}$, Jlenia Monfregola ${ }^{1}$, Antonio Maiorino ${ }^{4}$, Angela D'Eustacchio ${ }^{3}$, Valerio Ventruto ${ }^{1}$, Giovanni Neri², Michele D'Urso ${ }^{1}$, Pietro Chiurazzi ${ }^{2}$, Matilde Valeria Ursini ${ }^{1}$ and Maria Giuseppina Miano*1

Address: ${ }^{1}$ Institute of Genetics and Biophysics "Adriano Buzzati Traverso" CNR, Naples, Italy, ${ }^{2}$ Catholic University of Rome, Rome, Italy, ${ }^{3}$ Telethon Institute of Genetics and Medicine, TIGEM, Naples, Italy and ${ }^{4}$ C.A.R.S.I.C Institute, Venafro, Italy

Email: Carmela Laperuta - laperuta@igb.cnr.it; Letizia Spizzichino - miano@igb.cnr.it; Pio D'Adamo - miano@igb.cnr.it; Jlenia Monfregola - miano@igb.cnr.it; Antonio Maiorino - miano@igb.cnr.it; Angela D'Eustacchio - miano@igb.cnr.it;

Valerio Ventruto - miano@igb.cnr.it; Giovanni Neri - miano@igb.cnr.it; Michele D'Urso - miano@igb.cnr.it;

Pietro Chiurazzi - miano@igb.cnr.it; Matilde Valeria Ursini - ursini@igb.cnr.it; Maria Giuseppina Miano* - miano@igb.cnr.it

* Corresponding author

Published: 4 May 2007

BMC Medical Genetics 2007, 8:25 doi:10.1 186/147I-2350-8-25
Received: 22 November 2006

Accepted: 4 May 2007

This article is available from: http://www.biomedcentral.com/147/-2350/8/25

(c) 2007 Laperuta et al; licensee BioMed Central Ltd.

This is an Open Access article distributed under the terms of the Creative Commons Attribution License (http://creativecommons.org/licenses/by/2.0), which permits unrestricted use, distribution, and reproduction in any medium, provided the original work is properly cited.

\begin{abstract}
Background: Cognitive impairments are heterogeneous conditions, and it is estimated that $10 \%$ may be caused by a defect of mental function genes on the $X$ chromosome. One of those genes is Aristaless related homeobox $(A R X)$ encoding a polyA-rich homeobox transcription factor essential for cerebral patterning and its mutations cause different neurologic disorders. We reported on the clinical and genetic analysis of an Italian family with X-linked mental retardation (XLMR) and intrafamilial heterogeneity, and provided insight into its molecular defect.
\end{abstract}

Methods: We carried out on linkage-candidate gene studies in a new MRX family (MRX87). All coding regions and exon-intron boundaries of $A R X$ gene were analysed by direct sequencing.

Results: MRX87 patients had moderate to profound cognition impairment and a combination of minor congenital anomalies. The disease locus, MRX87, was mapped between DXS7I04 and DXS1214, placing it in Xp22-p2I interval, a hot spot region for mental handicap. An in frame duplication of 24 bp (ARXdup24) in the second polyAlanine tract (polyA_II) in ARX was identified.

Conclusion: Our study underlines the role of ARXdup24 as a critical mutational site causing mental retardation linked to Xp22. Phenotypic heterogeneity of MRX87 patients represents a new observation relevant to the functional consequences of polyAlanine expansions enriching the puzzling complexity of ARXdup24-linked diseases. 


\section{Background}

$\mathrm{X}$-linked mental retardation (XLMR) is a heterogeneous genetic condition characterized by variable cognitive handicap with IQ below 70. To date more than 50 XLMR genes have been recognized [1-3]. Each of them accounts for a very small proportion of the affected families with the exception of $F M R 1$, whose loss of function mutation causes the Fragile $\mathrm{X}$ syndrome, and the Aristaless $X(A R X)$ gene mutated in several syndromic and non syndromic mentally retarded patients [4-9].

The ARX gene (OMIM \#300382) was identified as the causative gene in several allelic brain diseases with MR such as i) XLAG or X-linked lissencephaly with abnormal genitalia (OMIM \#300215) [10]; ii) Proud syndrome or mental retardation with agenesis of the corpus callosum, microcephaly, limb contractures, scoliosis, coarse faces, tapered digits and urogenital abnormalities (OMIM \#30004) [10]; iii) myoclonic epilepsy syndrome (OMIM \#300432) [11]; iv) West syndrome or X-linked infantile spasm syndrome with hypsarrhythmia and mental retardation (OMIM \#308350) [12]; v) Partington dystonic syndrome (OMIM \#309510) [13]; vi) non syndromic Xlinked mental retardation (OMIM \#300382) [14].

$A R X$ encodes the Aristaless-related protein, a bi-functional homeobox transcription factor essential for cerebral patterning and for the maintenance of specific neuronal subtypes in the cerebral cortex [15]. It belongs to the $Q_{50}$ Paired-like (Prd-like) class genes, an ancient family of transcription factors with a key role in the early evolution of the animal head and development of the central nervous system [16]. The ARX protein contains a number of conserved domains, including the two DNA binding domains (Homeobox and Aristaless), and four distinct hydrophobic polyalanine tracts (polyA_I, II, III and IV) with a hypothetical role as transcriptional suppressor $[17,18]$.

The Arx knockout mouse is characterized by a small brain with aberrant migration and differentiation of GABAergic interneuron progenitors and altered testes, a complex phenotype similar to the human XLAG syndrome $[19,20]$. Murine expression studies showed that Arx is widespread throughout telencephalic structures implicated in the pathophysiology of learning formation $[13,14,20]$.

ARX gene represents a hot spot for mutations in families with cognition disorders because its mutations account for $9.5 \%$ of X-linked MR families [7]. The most frequent mutation is c.428_451dup24, also known as ARXdup24, a 24 bp duplication in exon 2 resulting in elongation of the second polyalanine tract ( polyA $_{12}$ II), that alone might account for $6.6 \%$ of all XLMR and $41 \%$ of families with mutations in ARX gene [4-9]. The c.428_451dup24 mutation has never been found in association with severe brain malformations (i.e. XLAG or Proud syndromes). However, variable phenotypic expression is often observed within the same family with c.428_451dup24 $[21,22]$ reinforcing the notion that $A R X$ is a pleiotropic gene that, in a diverse genetic context and/or under the influence of modifier genes, controls different aspects of human brain morphogenesis and function.

Here we present the molecular and clinical characterization of a new XLMR family (MRX87) linked to the Xp21 region in which we found the segregation of the c.428_451dup24 associated to intra-familial clinical variability. Our study aims to enrich the clinical and genetic description of mental defects due to polyalanine expansions in Aristaless protein.

\section{Methods \\ Ascertainment of family members}

Mental retardation was reported in five affected men of a four-generations Italian family (Figure 1). This family includes two affected brothers (IV:13 and IV:14), two affected first cousins (III:5 and III:10) and one affected great uncle (II:5). Peripheral venous blood samples were collected from family members. Informed consent had been obtained. Studies and procedures have been performed with the approval of the ethic committee of the host institutions according to the Helsinki Declaration. Karyotype analysis after G-banding was normal in all family members and molecular analysis of the Fragile X mutation was negative in all patients.

\section{Linkage analysis}

Genomic DNA was isolated from the nucleated peripheral blood leukocytes using the Salting out procedure. A standard set of microsatellite markers on the $\mathrm{X}$ chromosome, evenly spaced every $10 \mathrm{cM}$ (ABI PRISM Linkage Mapping Sets vs2, Applied Biosystems) was PCR amplified using conditions already described [3]. Thirteen individuals of the family were genotyped (Figure 1) and PCR products were analysed on automatic sequencer (ABI PRISM 3100, Applied Biosystem). Extra fluorescently labelled primers were synthesized for seven additional polymorphic markers chosen in public databases. Two-point linkage analysis was performed by the MLINK program version 5.1, from the LINKAGE software package [3]. The approved gene symbol MRX87 (Mental Retardation X-Linked 87) was assigned according to the HUGO (Human Genome Organization) nomenclature. X-inactivation status was tested by HUMARA (Human Androgen Receptor Gene) fluorescent assay according to Fimiani et al [23]. XCI patterns were classified as random $(\mathrm{XCI} \leq 70 \%)$, non random $(70 \% \leq \mathrm{XCI} \leq 80 \%)$ or skewed $(\mathrm{XCI} \geq 90 \%)$. 


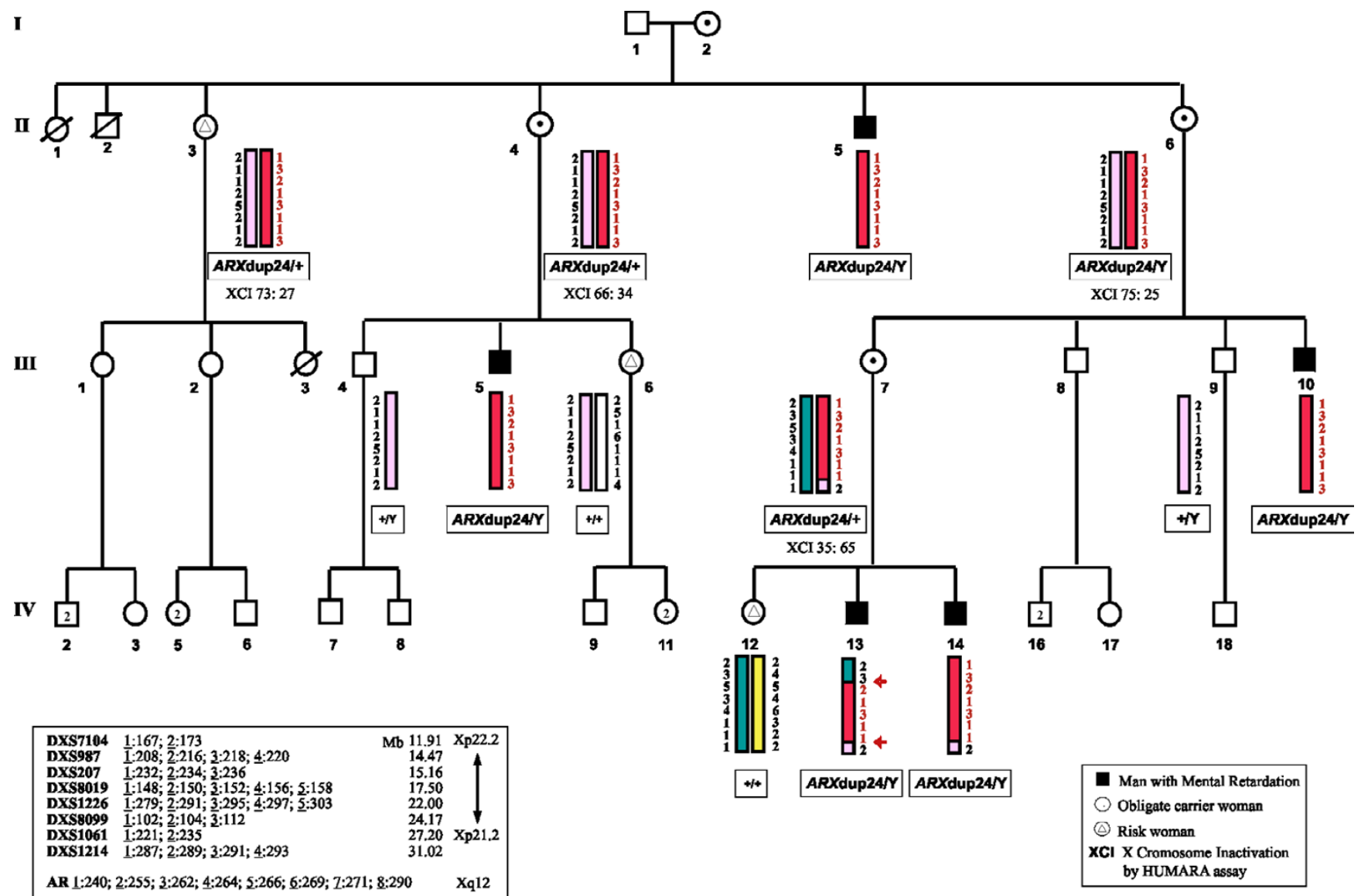

\section{Figure I}

The four-generation family with MRX87 haplotypes for markers in Xp22-p2I and segregation of $A R X$ mutation. Thirteen individuals from whom DNA was available were genotyped and linkage analysis was performed. Informative recombinations between the markers DXS987 and DXS207 and between DXSI06 I and DXSI 214 are indicated with the arrowheads. X disease haplotype $\left(X_{d}\right)$ is shown in red. The $X$ inactivation ratio, obtained by HUMARA (Human Androgen Receptor gene, AR) assay is indicated for each woman tested. The physical order of the markers analysed is, from telomere (top) to the centromere (bottom), as shown.

\section{Mutation analysis}

All coding exons and the flanking intronic sequences of the $A R X$ gene were amplified using DNA from affected and non-affected members of the MRX87 family. Eight primer pairs were used, namely: 1F 5'-CCA ACA CAC ACC CAT CCA T-3' and 1R 5'-CCG AAC ACC AAA CAT CCA A3' for exon 1; 2aF 5'-CAA GGC GTC GAA GTC TGG TG-3' and 2aR 5'-GTA CGA CTT GCT GCG GCT GA-3', 2bF 5'CTC CTT CAG GGT GCG GCA GC-3' and 2bR 5'-CCA GCA GCT CCT CCT CGT CG-3', 2cF 5'-CGT CAC GCA CCC GGA GGA GC-3' and 2cR 5'-AGC CCG CTG TCC CTC CCT GG-3' for exon 2; 3F 5'-TGG AGT AGG CCT GCC ATA GA-3' and 3R 5'-CCA ACC CAT CTC TCT CTC TCC-3' for exon 3; 4aF 5'-GCC AAG GGA AGG GAC GGG TA-3' and 4aR 5'-GGT AGG GGC TGA GCG GGT GG-3',
4bF 5'-GAG AAG GCA GGC GCG CAG AC-3' and 4bR 5'ACT CCT GCC TCC TCC CTG CC-3' for exon 4; 5F 5'-CCT CGG GGA ATA TCT GGA CT-3' and 5R 5'-TTG AGT GGT GCT GAG TGA GG-3' for exon 5. The PCR fragments were sequenced in both directions with the ABI PRISM 3100 DNA sequencer (Applied Biosystem). The 24 base pair duplication in exon 2 was also visualized in patients and carrier women by separating the PCR fragments of amplicon $2 \mathrm{a}(472 \mathrm{bp})$ and 2b (409 bp) on a 3\% agarose gel.

\section{Results}

Neurological and physical examination

A diagnosis of MR associated with minor anomalies was made after examination of the patients (II:5, III:5, III:10, IV:13 and IV:14; Figure 1) at the Neurological Center 
(CARSIC, Venafro, Italy). Careful examination of the patients' phenotypes was performed and the intelligence quotient was assessed by Wechsler Adult intelligence Scale (WAIS). All affected men were born at term after normal pregnancy; no statural growth deficiency was observed. No adverse prenatal events of interest were reported and an extensive metabolic work-up yielded negative results. None of them had convulsion or hand dystonia. All had normal vision and no gonad malformations were recorded.

Four of them (II:5, III:10, IV:13 and IV:14) were thoroughly examined and a marked intra-familial heterogeneity was observed. Patients presented a variable cognitive impairment, moderate in IV:13 and IV:14 and severe in II:5, III:5, and III:10. Their clinical evaluation was summarized in Table 1. No dysmorphic signs were observed (Figure 2). In patient II:5, we found pyramidal hypotonia, bilateral Babinski signs and demential behavior. Bilateral neurosensorial deafness and a deficit of the VII cranial nerve were also observed. These signs were not present in the other affected men. However, because II:5 is the oldest affected man in the pedigree, it is possible that these symptoms are age-related and may eventually manifest in the other patients at a later time. Unlike II:5, IV:13 and IV:14, whose MRI examinations did not reveal any structural alterations, patient III:10 showed enlarged subarachnoid spaces and cerebellar tonsils below the foramen magnum (data not shown). No signs of increased intracranial pressure or cortex lesions were detected in this patient.

Patient II:5 and patient IV:13 had severe urinary incontinence, a clinical sign often observed in association with MR [24]. Only in patient IV:14, we diagnosed a moderate intellectual handicap associated with a language deficit. Three out of four probands showed a flatfoot deformity (III:10, IV:13 and IV:14), a defect that was not evident in the unaffected men of the family. The obligate carrier women are of normal intelligence and clinically indistin- guishable from their non carrier sisters. No carrier mothers recalled serious abnormalities in pregnancy.

\section{MRX87 was linked to Xp22-Xp2I and is due to a dup24 mutation in the Aristaless related homeobox $X$ - chromosome linked gene}

Two-point linkage allowed mapping of the MRX87 locus to DXS987 marker in the Xp22-p21 interval. A maximum two point LOD score of 2.43 with no recombination was obtained for three adjacent markers in Xp22-Xp21.1 (DXS207, DXS8019, DXS1226; Figure 1 and Table 2). A double crossover was observed in the patient IV:13 defining the interval between the telomeric (DXS987-DXS207) and the centromeric (DXS1061-DXS1214) markers in which the disease gene was located (Figure 1).

This region contains the $A R X$ gene, that is, after FMR1, the most frequently mutated gene in syndromic and non syndromic X-linked mental retardation $[4,5,7]$. Therefore, we sequenced $A R X$ in the patients of MRX87 family for whom genomic DNA was available. After PCR analysis of the coding exons, the products were directly sequenced. We detected a 24-bp in frame duplication in exon 2, (c.428_451dup24 also known as ARXdup24) resulting in the duplication of nucleotides 428-451 (5'GCCGCCGCGGC AGCCGCGGCCGCG-3'; in GenBank Accession Number NM 139058; Figure 3). The ARXdup24 is the most frequent MR mutation found in the $A R X$ gene [7]. This duplication is an in frame expansion of the second poly-alanine tract of the ARX protein (amino acids 144-155) from 12 to 20 alanines (Figure 3 ). The ARXdup24 was found in all MRX87 male patients (II:5, III:5, III:10, III:13 and III:14) and was absent in the healthy men (III:4 and III:9). The obligate carriers (II:4, II:6, III:7) and at risk-women (II:3, III:6 and IV:12) were also tested. The ARXdup24 was present in all obligate carriers and in II:3, while III: 6 and IV:12 did not inherit the mutation (Figure 1). Testing was also performed for individual III:2 because of her mother's status (II:3), ascertaining the absence of c.428_451dup24.

Table I: Synopsis of MRX87 male patients

\begin{tabular}{|c|c|c|c|c|c|c|}
\hline Individual & Age & Mental handicap & Minor anomalies & Behavior & MRI/CT scan & OCF \\
\hline II:5 & $67 y$ & Severe & $\begin{array}{c}\text { Pyramidal Hypotonia; } \\
\text { Bilateral Babinski sign; } \\
\text { Deficit of the VII cranial nerve; } \\
\text { Urinary incontinence; } \\
\text { Neurosensorial hypoacusis }\end{array}$ & Demential syndrome & Normal & $52 \mathrm{~cm}$ \\
\hline III: 10 & $40 y$ & Severe & Flatfoot & $\mathrm{Nd}$ & $\begin{array}{l}\text { Cerebellar tonsils below the } \\
\text { level of the foramen magnum; } \\
\text { Wide subarachnoid spaces }\end{array}$ & $56 \mathrm{~cm}$ \\
\hline IV:I3 & $22 y$ & Moderate & $\begin{array}{c}\text { Flatfoot; } \\
\text { Urinary incontinence }\end{array}$ & $\mathrm{Nd}$ & Normal & $53 \mathrm{~cm}$ \\
\hline IV:I 4 & $16 y$ & Moderate & $\begin{array}{l}\text { Sialorrhoea; } \\
\text { Flatfoot }\end{array}$ & Language deficit & Normal & $54 \mathrm{~cm}$ \\
\hline
\end{tabular}

OCF = Occipital Circumference; Head and neck MRA - Sag TI, axial FLAIR, axial FSE T2. Nd = not determined. 

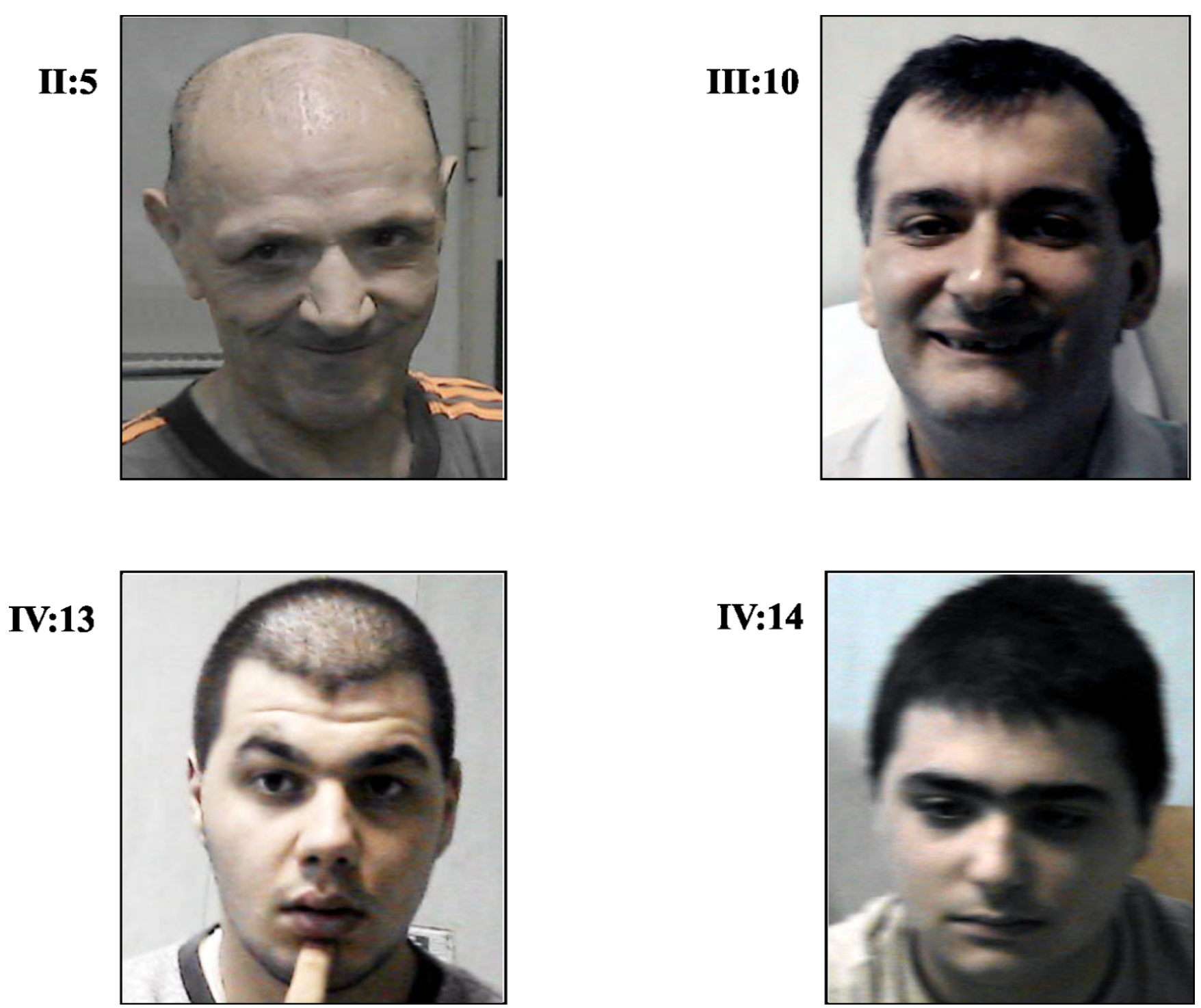

Figure 2

Affected men of MRX87 family with c.428_45I dup24 in ARX gene. No consistent facial features are present among the patients.

Table 2: Two-point LOD scores analysis across the markers DXS7 I40 and DXSI 14 linking MRX87 family to Xp22-p2I interval

\begin{tabular}{cccccccc}
\hline Marker & $\mathbf{0 . 0 *}$ & $\mathbf{0 . 0 1}$ & $\mathbf{0 . 0 5}$ & $\mathbf{0 . 1}$ & $\mathbf{0 . 2}$ & $\mathbf{0 . 3}$ & $\mathbf{0 . 4}$ \\
\hline DXS7I04 & -2.94 & 0.02 & 0.59 & 0.73 & 0.69 & 0.51 & 0.27 \\
DXS987 & 1.75 & 1.72 & 1.59 & 1.43 & 1.09 & 0.73 & 0.36 \\
DXS207 & 2.43 & 2.38 & 2.22 & 2.00 & 1.54 & 1.04 & 0.52 \\
DXS8019 & 2.35 & 2.31 & 2.15 & 1.94 & 1.50 & 1.02 & 0.52 \\
DXSI226 & 2.35 & 2.31 & 2.15 & 1.94 & 1.50 & 1.02 & 0.52 \\
DXS8099 & 1.75 & 1.72 & 1.59 & 1.43 & 1.09 & 0.73 & 0.36 \\
DXSI06I & 0.35 & 0.34 & 0.30 & 0.26 & 0.16 & 0.08 & 0.02 \\
DXSI214 & -7.31 & 0.31 & 0.87 & 0.99 & 0.90 & 0.66 & 0.35 \\
\hline
\end{tabular}

* Recombination fraction. 


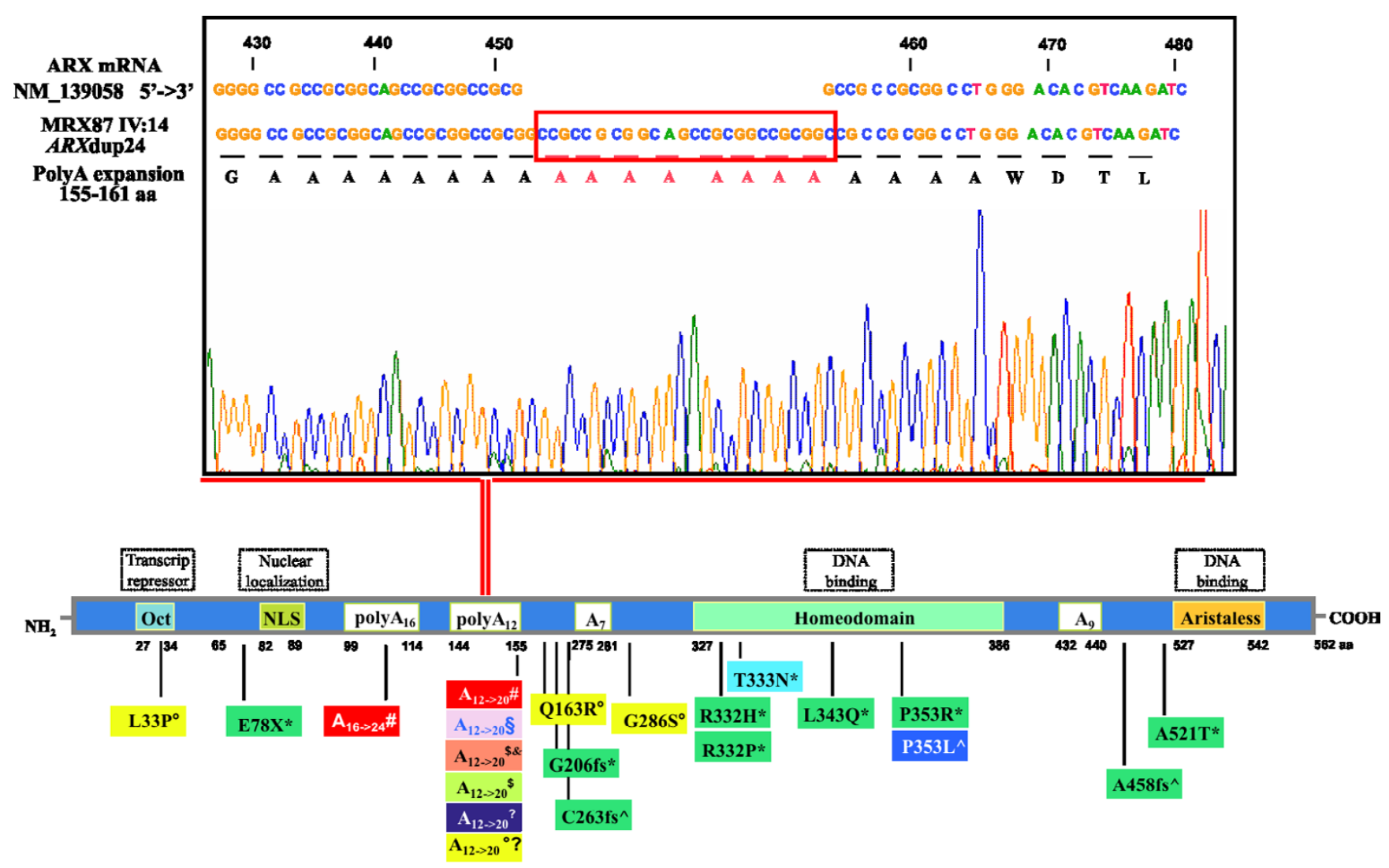

X-linked lissencephaly with ambiguos genitalia XLAG $\quad$ Agenesis of the corpus callosum, ACC $\square$ Myoclonic epilepsy syndrome

$\square$ MR with infantile spasms, ISSX $\square$ MRX with dystonia, PRST $\square$ MRX and seizures $\square$ MRX with brain cysts $\quad$ MRX with encephalocele $\square$ MRX

\section{Figure 3}

At the top of the figure: Electropherogram of amplicon b of the ARX exon 2 in MRX87 IV:I4. The box indicates the nucleotide sequence duplicated in the $A R X$ gene (c.428_45I dup24 also known as ARXdup24). At the bottom of the figure: ARX protein functional domains and polyA tracts are shown, next to the various mutations that results in a spectrum of developmental brain phenotypes. $*[10], \#[13],{ }^{\circ}[14], \wedge[19], \S[27], \Sigma[30], \neq[31], \$[32], \&[33]$.

$\mathrm{X}$ inactivation analysis (XCI) was performed in the leukocytes of four MRX87 carrier women (II:3, II:4, II:6 and III:7). We analysed the methylation status of the CpG islands of the AR gene, using the human Androgen Receptor gene fluorescent assay (HUMARA) and excluded the presence of skewed XCI in carrier women (Figure 1). This finding is not completely unexpected because most of the mutations that impair neurocognitive functioning do not confer a selective advantage in leukocytes, as in the case of individuals with Rett syndrome [25], or with Incontinentia Pigmenti [26]. Moreover, X-inactivation was measured in cells of an unaffected tissue (blood) but XCI may be different in the brain or at a critical time during brain development.

\section{Discussion}

This report describes the clinical and molecular findings of an Italian family with the ARXdup24 mutation (c.428_451dup24). We linked a new MRX condition,
MRX87, to Xp22-Xp21 interval. This is one of the three hot spot regions for X-linked mental retardation containing $A R X$, a gene prominently mutated in both syndromic and non syndromic cognitive impairments. By sequencing its coding region in the affected MRX87 males, we identified the recurrent mutation c.428_451dup24 [7]. This is a duplication of 24 bp in exon 2 that leads to an expansion of the second polyalanine tract (polyA_II) in the ARX protein, from 12 to 20 . As far as we know, there are at least 30 published families with c.428_451dup24 showing different clinical presentations including a mild MR to severe MR. Sometimes MR is observed alone, but more often, it is accompanied by a combinations of dystonia, autism, spinocerebellar ataxia, and seizures (Table 3). To this regard, the clinical evaluation of the MRX87 family contributed new elements that enrich the disease spectrum associated to $A R X$ mutations. Indeed, patients from our family displayed novel distinctive phenotypical features with a marked clinical intra-variability and varia- 
ble expression. In particular, a congenital hindbrain hernia, namely Arnold-Chiari like-malformation, was diagnosed in patient III:10. Chiari malformations are composed of a combination of brain stem and cerebellum anomalies. Among the families affected by ARXdup24, one was recently described with a boy who, apart from $\mathrm{MR}$, also had a series of congenital anomalies including encephalocele [27], a neurological defect that may occur in association with Arnold-Chiari malformations [28]. Both malformations may be classified as failure of separation of neuro-ectodermal elements from the neural crest [29].

The ARXdup24 underlies only a part of the complex phenotypic spectrum of $A R X$ mutations. We can distinguish three groups of $A R X$ mutations with different outcomes (Figure 3) [10-14,19,27,30-33]: 1. severe mutations causing severe brain patterning malformations due to alterations of the DNA binding domains (HD and Aristaless); 2. expansion in the polyA_I motif causing familial ISSX phenotypes; 3. expansion in the polyA_II motif (c.428_451dup24) causing a spectrum of XLMR conditions with huge inter- and intra-familial heterogeneity. With the exception of the severe $A R X$ alterations classified as "loss of function", we cannot establish the functional effect of the polyA expansion mutations. Indeed, in vitro data, obtained for only the polyA_I motif, are still controversial $[34,35]$ and no transgenic mice has been produced for each polyA mutation. On the other hand because ARX expansions in both motifs cause varying degree of MR in humans, the functions of the polyA tracts in the ARX protein could be related to the complexity of brain functions such as those controlling memory and learning.

\section{Conclusion}

In conclusion, the identification of a new MRX family linked to Xp22 and carrying the c.428_451dup24 (ARXdup24) underlines the high contribution of $A R X$ to $\mathrm{X}$ linked mental retardation. Furthermore, the clinical findings of the affected members of the MRX87 family enhance the striking phenotypic variability associated with polyA_II expansion.

\section{Electronic resources}

A number of different electronic resources were used in the research for this article. These are listed in the main reference list [36-42].

\section{Competing interests}

The author(s) declare that they have no competing interests.

\section{Authors' contributions}

CL carried out mutational analysis, $\mathrm{X}$ inactivation study and participated in the bioinformatic study. LS participated in the nucleotide sequence analysis and mutation identification. PD carried out statistical study. JM participated in the bioinformatic study. AM carried out clinical characterization of the patients. AD performed genotyping. VV identified and diagnosed the patients. GN participated in genetic counselling. MD participated in the design of the study. PC participated in genetic analysis. MVU participated in the design of the study and helped to draft the manuscript. MGM conceptualized, designed the study and drafted the manuscript. All authors read and approved the final manuscript.

Table 3: Summary of clinical data observed in other ARXdup24 families

\begin{tabular}{|c|c|c|c|c|c|}
\hline Families & Mental handicap & Minor anomalies & Behavior & MRI/CT scan & References \\
\hline MRX54 & Moderate to profound & $\begin{array}{l}\text { Long face, thin lips, large ears, } \\
\text { epilepsy }\end{array}$ & Aggressive & Normal & {$[14]$} \\
\hline P73-MRX & Moderate & No & Language deficit & Normal & {$[14]$} \\
\hline P49-MRX & Moderate & Dystonia & $\begin{array}{l}\text { Language deficit, } \\
\text { hyperkinesia }\end{array}$ & Normal & {$[14]$} \\
\hline MRX36 & Moderate to severe & No & Normal & Normal & {$[14]$} \\
\hline MRX43 & Moderate to severe & Obesity, large head, epilepsy & Normal & ND & {$[14]$} \\
\hline MRX76 & Moderate & Wolff-Parkinson- White & $\begin{array}{c}\text { Depressive and } \\
\text { psychotic features }\end{array}$ & ND & {$[14]$} \\
\hline P34-MRX & Severe & $\begin{array}{l}\text { General developmental delays, } \\
\text { dystonic hand movements }\end{array}$ & Language deficit & Normal & {$[6]$} \\
\hline PI04-MRX & Severe & No & No & Normal & {$[6]$} \\
\hline PI06-MRX & Moderate & No & $\begin{array}{l}\text { Severe language } \\
\text { development delay }\end{array}$ & Normal & [6] \\
\hline T37-MRX & Severe & $\begin{array}{l}\text { Long chin and deep-set eyes, } \\
\text { strabismus, neonatal hypotonia }\end{array}$ & $\begin{array}{l}\text { Learning and walking } \\
\text { difficulties }\end{array}$ & Normal & {$[6]$} \\
\hline$A R X$ family & Severe & $\begin{array}{l}\text { Hypertelorism, broad nasal } \\
\text { root, cleft upper lip, growth } \\
\text { hormone deficiency }\end{array}$ & Psychomotor delay & $\begin{array}{l}\text { Transsphenoidal encephalocele } \\
\text { and agenesis of corpus callosum } \\
\text { (ACC) and hypopituitarism }\end{array}$ & [27] \\
\hline
\end{tabular}

ND = not determined 


\section{Acknowledgements}

The authors are greatly indebted to the patients and their parents for contributing blood samples and medical records. They would like to thank $C$. Carbone for technical assistance. Work on XLMR in our laboratories was supported by FIRB grant from MIUR-Italy. The research conducted in this study complies with current Italian laws. Written consent was obtained from their relative for publication of the patient's details and their photographs.

\section{References}

I. Chiurazzi P, Tabolacci E, Neri G: X-linked mental retardation (XLMR): from clinical conditions to cloned genes. Crit Rev Clin Lab Sci 2004, 4 I: I I7-I58.

2. Ropers $\mathrm{HH}$, Hamel $\mathrm{BC}$ : X-linked mental retardation. Nat Rev Genet 2005, 6:46-57.

3. Annunziata I, Lanzara C, Conte I, Zullo A, Ventruto V, Rinaldi MM, D'Urso M, Casari G, Ciccodicola A, Miano MG: Mapping of MRX8 I in $\mathrm{XpI}$ I.2-Xq I 2 suggests the presence of a new gene involved in nonspecific $\mathbf{X}$-linked mental retardation. Am J Med Genet $A$ 2003, I I 8:217-222.

4. Mandel JL, Chelly J: Monogenic X-linked mental retardation: is it as frequent as currently estimated? The paradox of the ARX (Aristaless X) mutations. Eur J Hum Genet 2004, I 2:689-693.

5. Poirier K, Lacombe D, Gilbert-Dussardier B, Raynaud M, Desportes V, de Brouwer AP, Moraine C, Fryns JP, Ropers HH, Beldjord C, Chelly J, Bienvenu TL: Screening of ARX in mental retardation families: consequences for the strategy of molecular diagnosis. Neurogenetics 2006, 7:39-46.

6. Poirier K, Abriol J, Souville I, Laroche-Raynaud C, Beldjord C, Gilbert $B$, Chelly J, Bienvenu T: Maternal mosaicism for mutations in the ARX gene in a family with $X$ linked mental retardation. Hum Genet 2005, I I 8:45-8.

7. Gecz J, Cloosterman D, Partington M: ARX: a gene for all seasons. Curr Opin Genet Dev 2006, I6:308-316.

8. Nawara M, Szczaluba K, Poirier K, Chrzanowska K, Pilch J, Bal J, Chelly J. Mazurczak T: The ARX mutations: a frequent cause of $\mathbf{X}$ linked mental retardation. Am J Med Genet A 2006, I 40:727-32.

9. Gestinari-Duarte Rde S, Santos-Reboucas CB, Boy RT, Pimentel MM: ARX mutation c.428-45 I dup (24 bp) in a Brazilian family with X-linked mental retardation. Eur J Med Genet 2006, 49:269-75.

10. Kato M, Das S, Petras K, Kitamura K, Morohashi K, Abuelo DN, Barr M, Bonneau D, Brady AF, Carpenter NJ, Cipero KL, Frisone F, Fukuda $T$, Guerrini R, lida E, Itoh M, Lewanda AF, Nanba Y, Oka A, Proud VK, Saugier-Veber P, Schelley SL, Selicorni A, Shaner R, Silengo M, Stewart F, Sugiyama N, Toyama J, Toutain A, Vargas AL, Yanazawa M, Zackai $\mathrm{EH}$, Dobyns WB: Mutations of ARX are associated with striking pleiotropy and consistent genotype-phenotype correlation. Hum Mutat 2004, 23: I47-I59.

II. Scheffer IE, Wallace RH, Phillips FL, Hewson P, Reardon K, Parasivam G, Stromme P, Berkovic SF, Gecz J, Mulley JC: X-linked myoclonic epilepsy with spasticity and intellectual disability: mutation in the homeobox gene ARX. Neurology 2002, 59:348-356.

12. Kato M, Das S, Petras K, Sawaishi Y, Dobyns WB: Polyalanine expansion of ARX associated with cryptogenic West syndrome. Neurology 2003, 61:267-276.

13. Stromme P, Mangelsdorf ME, Shaw MA, Lower KM, Lewis SM, Bruyere $H$, Lutcherath V, Gedeon AK, Wallace RH, Scheffer IE, Turner G, Partington M, Frints SG, Fryns JP, Sutherland GR, Mulley JC, Gecz J: Mutations in the human ortholog of Aristaless cause $X$-linked mental retardation and epilepsy. Nat Genet 2002, 30:44I-445.

14. Bienvenu T, Poirier K, Friocourt G, Bahi N, Beaumont D, Fauchereau $F$, Ben Jeema L, Zemni R, Vinet MC, Francis F, Couvert P, Gomot M, Moraine C, van Bokhoven H, Kalscheuer V, Frints S, Gecz J, Ohzaki K, Chaabouni H, Fryns JP, Desportes V, Beldjord C, Chelly J: ARX, a novel Prd-class-homeobox gene highly expressed in the telencephalon, is mutated in X-linked mental retardation. Hum $\mathrm{Mol}$ Genet 2002, I I:981-991.

15. Miura H, Yanazawa M, Kato K, Kitamura K: Expression of a novel aristaless related homeobox gene 'Arx' in the vertebrate telencephalon, diencephalon and floor plate. Mech Dev 1997, 65:99-109.

16. Galliot B, Miller D: Origin of anterior patterning. How old is our head? Trends Genet 2000, I 6: I-5

17. Han K, Manley JL: Functional domains of the Drosophila Engrailed protein. Embo J 1993, I 2:2723-2733.

18. Brown LY, Brown SA: Alanine tracts: the expanding story of human illness and trinucleotide repeats. Trends Genet 2004, 20:5 I-58.
19. Kitamura K, Yanazawa M, Sugiyama N, Miura H, lizuka-Kogo A, Kusaka M, Omichi K, Suzuki R, Kato-Fukui Y, Kamiirisa K, Matsuo M, Kamijo S, Kasahara M, Yoshioka H, Ogata T, Fukuda T, Kondo I, Kato M, Dobyns WB, Yokoyama M, Morohashi K: Mutation of ARX causes abnormal development of forebrain and testes in mice and $X$ linked lissencephaly with abnormal genitalia in humans. Nat Genet 2002, 32:359-369.

20. Colombo E, Galli R, Cossu G, Gecz J, Broccoli V: Mouse orthologue of ARX, a gene mutated in several X-linked forms of mental retardation and epilepsy, is a marker of adult neural stem cells and forebrain GABAergic neurons. Dev Dyn 2004, 23I:63I-639.

21. Turner G, Partington M, Kerr B, Mangelsdorf M, Gecz J: Variable expression of mental retardation, autism, seizures, and dystonic hand movements in two families with an identical ARX gene mutation. Am I Med Genet 2002, I I 2:405-4 I I.

22. Gronskov K, Hjalgrim H, Nielsen IM, Brondum-Nielsen K: Screening of the ARX gene in $\mathbf{6 8 2}$ retarded. Eur J Hum Genet 2004, I 2:701-705

23. Fimiani $G$, Laperuta $C$, Falco $G$, Ventruto $V$, D'Urso $M$, Ursini $M V$ Miano MG: Heterozygosity mapping by quantitative fluorescent $P C R$ reveals an interstitial deletion in Xq26.2-q28 associated with ovarian dysfunction. Hum Reprod 2006, 2 I:529-535.

24. Lott IT, Lai F: Dementia in Down's syndrome: observations from a neurology clinic. Appl Res Ment Retard 1982, 3:233-239.

25. Takagi $\mathrm{N}$ : The role of $\mathbf{X}$-chromosome inactivation in the manifestation of Rett syndrome. Brain Dev 200I, 23:SI 82-I85.

26. Fusco F, Bardaro T, Fimiani G, Mercadante V, Miano MG, Falco G, Israel A, Courtois G, D'Urso M, Ursini MV: Molecular analysis of the genetic defect in a large cohort of IP patients and identification of novel NEMO mutations interfering with NF-kappaB activation. Hum Mol Genet 2004, I3:1763-1773.

27. Van Esch H, Poirier K, de Zegher F, Holvoet M, Bienvenu T, Chelly J, Devriendt K, Fryns JP: ARX mutation in a boy with transsphenoidal encephalocele and hypopituitarism. Clin Genet 2004, 65:503-505.

28. Haberle J, Hulskamp G, Harms E, Krasemann T: Cervical encephalocele in a newborn - Chiari III malformation. Case report and review of the literature. Childs Nerv Syst 200I, I 7:373-375.

29. Matsuoka T, Ahlberg PE, Kessaris N, lannarelli P, Dennehy U, Richardson WD, McMahon AP, Koentges G: Neural crest origins of the neck and shoulder. Nature 2005, 436:347-355.

30. Stromme P, Bakke SJ, Dahl A, Gecz J: Brain cysts associated with mutation in the Aristaless related homeobox gene, ARX. J Neurol Neurosurg Psychiatry 2003, 74:536-538.

31. Stepp ML, Cason AL, Finnis M, Mangelsdorf M, Holinski-Feder E, Macgregor D, MacMillan A, Holden JJ, Gecz J, Stevenson RE, Schwartz CE: XLMR in MRX families 29,32, 33 and 38 results from the dup24 mutation in the ARX (Aristaless related homeobox) gene. BMC Med Genet 2005, 6:16.

32. Partington MW, Turner G, Boyle J, Gecz J: Three new families with $X$-linked mental retardation caused by the 428-45 I dup( 24 bp) mutation in ARX. Clin Genet 2004, 66:39-45

33. Frints SG, Froyen G, Marynen P, Willekens D, Legius E, Fryns IP: Reevaluation of MRX36 family after discovery of an ARX gene mutation reveals mild neurological features of Partington syndrome. Am J Med Genet 2002, II 2:427-428.

34. Albrecht AN, Kornak U, Boddrich A, Suring K, Robinson PN, Stiege AC, Lurz R, Stricker S, Wanker EE, Mundlos S: A molecular pathogenesis for transcription factor associated poly-alanine tract expansions. Hum Mol Genet 2004, I 3:235 I-2359.

35. Nasrallah IM, Minarcik JC, Golden JA: A polyalanine tract expansion in Arx forms intranuclear inclusions and results in increased cell death. J Cell Biol 2004, 167:4 II-4I6.

36. Ensembl Genome DataBase [http://www.ensembl.org/]

37. GDB [http://www.gdb.org/]

38. GenBank [http://www.ncbi.nlm.nih.gov/]

39. Human Genome Organization (HUGO) [http:// www.gene.ucl.ac.uk/]

40. Linkage software [http://www.rockefeller.edu/]

41. OMIM [http://www.ncbi.nlm.nih.gov/Omim/]

42. UCSC [http://genome.ucsc.edu/]

\section{Pre-publication history}

The pre-publication history for this paper can be accessed here:

http://www.biomedcentral.com/1471-2350/8/25/prepub 